\title{
Information Sharing As Source Of Synergy Creation In Corporate Diversification: An Empirical Analysis Of Korean Banking Industry
}

Chul Woo Moon, Sungkyunkwan University, Korea

\begin{abstract}
This paper deals with one of the major issues in strategy and finance research streams i.e. the strategic use of valuable information among different business units of diversified firms. In particular, the paper studies the effect of information sharing between a commercial bank and a securities firm under the same financial group on analysts' forecasts using Korean data over the period of 2000-2008. We find that the mean (median) EPS forecast error issued by independent analysts is $2.71 \%(1.34 \%)$ while that issued by bank-affiliated analysts is $2.09 \%(1.02 \%)$. The difference remains statistically significant even after controlling for company and analyst characteristics in multivariate analyses. The results are consistent with superior information hypothesis in that the bank-affiliated analysts make more accurate and conservative recommendations using the information generated by the commercial banks about the companies covered. This evidence suggests the efficiency of related-type business diversification which tends to foster the exchanges of value-generating information among business units.
\end{abstract}

Keywords: information sharing; diversification strategy; universal banking; analysts' forecasts; bank-affiliated analysts

\section{INTRODUCTION}

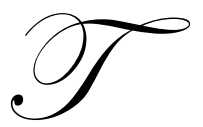

he performance effects of firm diversification have been extensively researched in the strategy and finance literature. The literature on diversification focuses on the economic rationale behind the diversification-performance relationship. Depending on whether the new business is similar or related to existing businesses, firms may diversify into related markets or unrelated markets. Related diversification is believed to lead to better performance than unrelated diversification because the former leverages significant business synergies while the latter suffers from agency costs and inefficient resource allocation (Amit \& Livnat, 1988).

Teece $(1980,1982)$ theorized that the motive for diversification revolved around the reuse of physical resources, technological resources, and other intangible resources such as brand and reputation, which are indivisible and subject to market failure. The implied scope economies or synergies in key production factors or value-chain processes entail the well-acknowledged notion that related diversifiers outperform single-business firms or unrelated diversifiers (Palich, Cardinal \& Miller, 2000; Rumelt, 1982; Tallman \& Li, 1996). In related diversifiers, cross-unit business synergies can be created by, among others, intrafirm knowledge sharing (Alavi \& Leidner, 2001; Tanriverdi, 2005). This study addresses the event of such information sharing among business units as source for value creation in corporate diversification strategy by investigating the example of Korean banking industry.

Since the 1990s Korean banking industry has consolidated through continuous mergers and acquisitions. Recently, Hana Financial Group tries to acquire Korea Exchange Bank over the period of 2010-2011. The industry 
is now dominated by the four largest financial conglomerates, Kookmin, Woori, Shinhan, and Hana. Under each financial conglomerate, subsidiaries offer commercial banking as well as investment banking services, such as loans and deposits, debt and equity underwriting, and analyst coverage. This financial conglomerate is similar to universal banking system in the U.S. since each financial group includes both commercial banking and investment banking businesses under one umbrella. Under post-Great Depression laws, banking holding companies in the U.S. were not allowed to own investment banks while no such division existed in the Europe. There has been considerable debates concerning the benefits and costs of the universal banking system since the U.S. relaxed the Glass-Steagall Act to allow commercial banks to participate in corporate securities underwritings in 1987. The U.S. repealed the Act in 1999 and allowed the universal banking since then. The global financial crisis over the period of 2007-2009 has reignited the controversy about the separation vs. integration of commercial and investment banking as many banking holding companies have acquired securities firms. The governor of the Bank of England argued in January 2010 that big banks must separate their higher-risk trading and investment banking businesses from their core deposittaking functions. In 2010, President Obama also proposed that large banks collecting customer deposits be banned from engaging in proprietary trading activities. However, many practitioners have opposed the idea of separating investment banking services from commercial banks. While academic researchers have investigated the effect of universal banking on debt and equity underwriting, they neglect the accuracy of bank-affiliated analysts' forecasts. In this study, we try to fill this void.

As a subsidiary of a financial conglomerate, a commercial bank can exploit the information generated inhouse by their lending activities for other businesses. Previous literature has extensively studied the certification role when commercial banks underwrite equities and bonds. For instance, Krozner and Rajan (1994) examine bonds issued during the pre-Glass-Steagall period in the U.S. and find that among unrated issues, those that were underwritten by bank affiliates are less likely to default than those were underwritten by independent houses. Massa and Rehman (2008) also examine the information flows between commercial banks and mutual funds within the same financial group. They find that funds increase their stakes in the firms that borrow from their affiliated banks than other unaffiliated funds, and the performance of the positions of affiliated funds in the stocks of borrowing firms tend to be better. While previous literature has examined the effect of universal banking on the pricing of securities or banks-mutual funds relation, we investigate whether knowledge spillovers regarding borrowing firms influence the accuracy of analysts' earnings forecasts using Korean data. It is our understanding that this research is the first to study the relation between the universal banking and analysts' forecasts.

In Korea, bank holding companies have commercial banks and securities firms (or investment banks) as subsidiaries. The tying of commercial banking and investment banking under the bank holding companies can be viewed as a universal banking. Housing commercial banks and securities firms under the same roof could facilitate the transmission of information. They can share the information through resource sharing, key personnel exchanges, and personal acquaintances. In addition, when the securities firm underwrites securities of a company or issue analysts' reports about the company, it can refer to the information produced by the commercial bank under the same bank holding company. In an extreme case, bank-affiliated analysts could even be able to use the inside information acquired from the lending activity of the commercial bank to produce their reports. Although the universal banking system can have a significant effect on financial markets, there has been little research on the Korean universal banking system.

Korean commercial banks have founded securities firms since the 1990s. All of the four largest Korean Financial Groups, KB, Shinhan, Woori, and Hana, have investment banks and commercial banks as subsidiaries as of 2008. In addition, Korea Development Bank, IBK, and NH Bank have affiliated securities firms. Out of 35 local securities firms, seven firms (20\%) are operated under the universal banking system. The firms routinely produce analysts' reports as well as underwrite securities. If bank-affiliated analysts can share the information that the affiliated commercial bank has accumulated about industrial companies by making and monitoring loans to the companies, they can have an informational advantage compared to other analysts when producing research reports. Since analysts tend to be overly optimistic about the companies they cover, we posit that the bank-affiliated analysts make more pessimistic forecasts than other analysts. We call this conjecture "superior information hypothesis".

To test the hypothesis, we first classify Korean local analysts as bank-affiliated analysts and unaffiliated analysts. The bank-affiliated analysts work for the securities firms which are subsidiaries of banking holding 
companies or affiliated with commercial banks while unaffiliated analysts work for other securities firms. We compare the bank-affiliated analysts' earnings forecasts on Korean industrial companies to other analysts' forecasts over the period of 2000-2008. We test the difference in the errors of the forecasts for the fiscal year-end earnings per share (EPS) issued by unaffiliated (or independent) versus bank-affiliated analysts.

The mean (median) EPS forecast error issued by independent analysts is $2.71 \%(1.34 \%)$ while that issued by bank-affiliated analysts is $2.09 \%(1.02 \%)$. The difference is statistically significant with a p-value of less than 0.01 . We also find that the mean (median) absolute forecast error issued by independent analysts is significantly larger than that issued by bank-affiliated analysts. These results suggest that the bank-affiliated analysts make more conservative and accurate forecasts than independent analysts. In multivariate regression tests, the difference remains statistically significant even after controlling for company and analyst characteristics. The results are consistent with superior information hypothesis. Information sharing between the commercial banks of borrowing company and affiliated securities firms results in more accurate forecasts by the bank-affiliated analysts. The evidence corroborates the positive effects of universal banking system on financial intermediation. Overall, our study contributes to extant literature by documenting the supporting evidence for the controversial universal banking system.

The next section presents a summary of prior studies related to this research and develops the hypothesis. Section 3 discusses the data used in this research and Section 4 presents empirical results. Section 5 concludes this study.

\section{LITERATURE REVIEW AND HYPOTHESES DEVELOPMENT}

Commercial banks obtain information about a firm over the period by making and monitoring loans to the firm. Unlike commercial banks, investment banks do not acquire private information from lending activities. Therefore, commercial banks can be better informed than investment banks about the firm. When commercial banks can underwrite securities issued by the firm, their underwritings can have a stronger certification effect than those of investment banks. However, underwritings of commercial banks can create a conflict of interest. For instance, by underwriting securities they privately know to be very risky and by requiring that the proceeds from the issue be used to pay down loans, the commercial banks can protect their own interests at the expense of investors buying the securities. In contrast, underwritings of investment banks do not create the same conflict of interest since the investment banks do not make loans to the firm. That is, the universal banking system has the benefit of the stronger certification effect as well as the cost of the conflict of interest.

This research is related to previous literature on universal banking and the accuracy of analysts' forecasts. Previous studies have documented conflicting evidences which support the benefits or costs of the universal banking system. Using the U.S. data, researchers generally find evidences supporting a stronger certification role of universal banks. Similar to Krozner and Rajan (1994), Puri (1996) finds that, prior to the Great Depression, investors paid higher prices for industrial bonds and preferred stock underwritten by commercial banks than for those underwritten by independent investment banks. Gande, Puri, Saunders, and Walter (1997) also document that, among bonds issued with a low credit rating over the period of 1993-1995, bank underwritten bonds earn lower yields than do bonds underwritten by investment banks. Drucker and Puri (2003) find that, using a large sample of seasoned equity offerings, universal banks reduce issuers' financing costs. In contrast, Kang and Liu (2007) find the evidence supporting the view of conflicts of interest created by universal banks using Japanese data. In this research, we examine the effect of the integration of commercial and investment banking in Korea on the accuracy of analysts' forecasts.

Analyst optimism has been well documented in the previous literature ${ }^{1}$. For instance, Fang and Yasuda (2006) find that buy recommendations in general do not contain information that is useful to investors since analysts tend to give overoptimistic advice. Previous lending relationships allow a commercial bank to acquire private information about its client companies. We conjecture that since affiliated banks accumulate the information about the companies they make loans to, bank-affiliated analysts have superior information about those companies that

\footnotetext{
${ }^{1}$ Refer to Mehran and Stulz (2007) for a survey of analysts' conflicts of interest. 
external analysts do not have due to blocked access." Through information sharing, the bank-affiliated analysts can issue more conservative and accurate earnings forecasts than other analysts. Therefore, we test the following main hypothesis:

H0: The bank-affiliated analysts issue more conservative and accurate earnings forecasts than other analysts.

Our research is also related to previous findings on the accuracy of the analysts' forecasts. The literature has documented considerable evidences that analysts' forecasts are affected by conflicts of interest. Sell-side analysts working for an investment bank have pressure to provide optimistic recommendations on firms that can provide business to the investment bank, or to raise funds to repay loans to the commercial bank. Analysts working in brokerage houses also have pressure to provide optimistic recommendations to attract trading revenues because upgrades attract more business than downgrades due to restrictions in short selling. ${ }^{2}$ The potential for this conflict of interest has spurred a large body of literature. ${ }^{3}$ Dugar and Nathan (1995), Michaely and Womack (1999), Cowen et al. (2006), Ljungqvist et al. (2007), and Agrawal and Chen (2008) find evidence consistent with the conflict of interest that analysts affiliated with investment banks and brokers produce more optimistic earnings and are more likely to give buy recommendations. The affiliated analysts are slower to revise downward their buy and hold recommendations (O'Brien, McNichols and Lin (2005)). They also issue buy (sell) recommendations that underperform (outperform) those issued by non-affiliated analyst (Cliff (2004) and Barber, Lehavy and Trueman (2007)). In addition, Mola (2005) finds empirical evidences that analysts of the lead underwriter have a tendency to downgrade companies that are competitors of their own underwritten IPOs, in order to support their own issues.

Some empirical studies do not support the conflicts of interest hypothesis. For instance, Clarke et al. (2004) find less optimistic and more accurate forecasts for the analysts of large investment banks compared to independent analysts. Jacob, Rock, and Weber (2008) find that short-term earnings forecasts made by investment banks are more accurate and less optimistic than those made by independent research firms. Clarke et al. (2007) document that All-Star analysts resist pressures from investment bankers. They argue that the information advantage result in a high research quality of the affiliated analysts compared to the unaffiliated analysts. Our study is similar to this line of research in that the Korean bank-affiliated analysts make use of informational advantage from the universal banking system. The bank analysts can use the information generated by the affiliated-banks of companies covered when they issue earnings forecasts for the companies.

\section{DATA}

To investigate the accuracy and optimism of bank-affiliated analysts' forecasts, we will first obtain the analysts' forecast data on South Korean companies from a database, FnConsensus of FnGuide. The South Korean financial data provider, FnGuide, collects data on local analysts' reports since 2000. Due to this time limitation of the FnGuide's data, our sample includes analysts' forecasts over the period of 2000-2008. We focus on local analysts' reports since Bae, Stulz, and Tan (2008) document that local analysts make more precise earnings forecasts for companies in their countries than foreign analysts. We focus on the main product made by the analysts, fiscalyear-end earnings (EPS) forecasts in our sample, but exclude upcoming quarterly earnings forecasts for the companies covered. Even though annual reports of companies are available two or three months after the end of a fiscal year, some information on earnings in the previous year is available right after the fiscal year-end. Therefore, we exclude the analysts' reports if the reports are issued after the end of a fiscal year. We also exclude financial companies, since such companies are heavily regulated and less subject to information asymmetry than are industrial companies. Our sample includes 106,034 EPS forecasts on 1,157 distinctive companies covered by some of 972 distinctive analysts. The companies are covered during some or whole sample period of 2000-2008. We get the issue dates of earnings forecasts, the names of security firms the analysts work for, and the closing stock prices on issuing dates from the FnConsensus.

We then combine accounting and stock return data with the analysts' forecasting data. We obtain annual accounting data on the companies covered by analysts from Total Solution 2000 (TS 2000), a database compiled by

\footnotetext{
${ }^{2}$ In the US the Security and Exchange Commission makes these conflict of interest available to investors at http://www.sec.gov/investor/pubs/analysts.htm.

${ }^{3}$ Mehran and Stutz (2007) provide an excellent summary of this literature.
} 
the Korean Listed Companies' Association. We also obtain stock return data of the sample companies and Korean market index around the issue dates of analysts' reports from a database (KIS-value) of Korean Information Service (KIS). The KIS is affiliated with the Moody's and is a leading provider of credit-related information and service in South Korea.

Table 1 lists the names of commercial banks and the names of securities firms affiliated with the banks. All of the four largest financial groups in Korea have commercial banks and securities firms as subsidiaries as of 2008. Korean Development Bank, IBK, and NH Bank also own securities firms as subsidiaries. Out of 29 local securities firms in our sample, 7 firms (24\%) are affiliated with commercial banks as of 2008. If analysts work for the 7 securities firms, they are classified as bank-affiliated analysts while other analysts are classified independent analysts.

Table 1: Securities Firms Under Universal Banking System

\begin{tabular}{|l|l|}
\hline Commercial bank or banking holding company name & Securities firm name affiliated with the bank \\
\hline KB Financial Group & KB Investment \& Seccurities \\
\hline Shinhan Financial Group & Shinhan Investment \\
\hline Hana Financial Group & Hana Daetoo Securities \\
\hline Woori Financial Group & Woori Investment \& Securities \\
\hline IBK & IBK Investment \& Securities \\
\hline Korea Development Bank & Daewoo Securities \\
\hline NH Bank & NH Investment \& Securities \\
\hline
\end{tabular}

We report the number of companies covered, analysts, and securities firms, and descriptive statistics on analyst characteristics in Table 2. Panel A of Table 2 presents the number of companies followed by analysts, the number of bank-affiliated and independent analysts, and the number of securities firms year by year. In 2000,332 industrial companies are followed by analysts while 529 companies are covered in 2008. Bank-affiliated analysts account for about 20\% (24) out of 139 analysts in 2000 while they account for about $27 \%$ (135) out of 485 analysts in 2008. Over the period of 2000-2008, bank-affiliated analyst-years represent $21 \%$ (701) out of 3,313 analystyears. The number of securities firms ranges from 26 to 33 firms each year.

Table 2: Descriptive Statistics

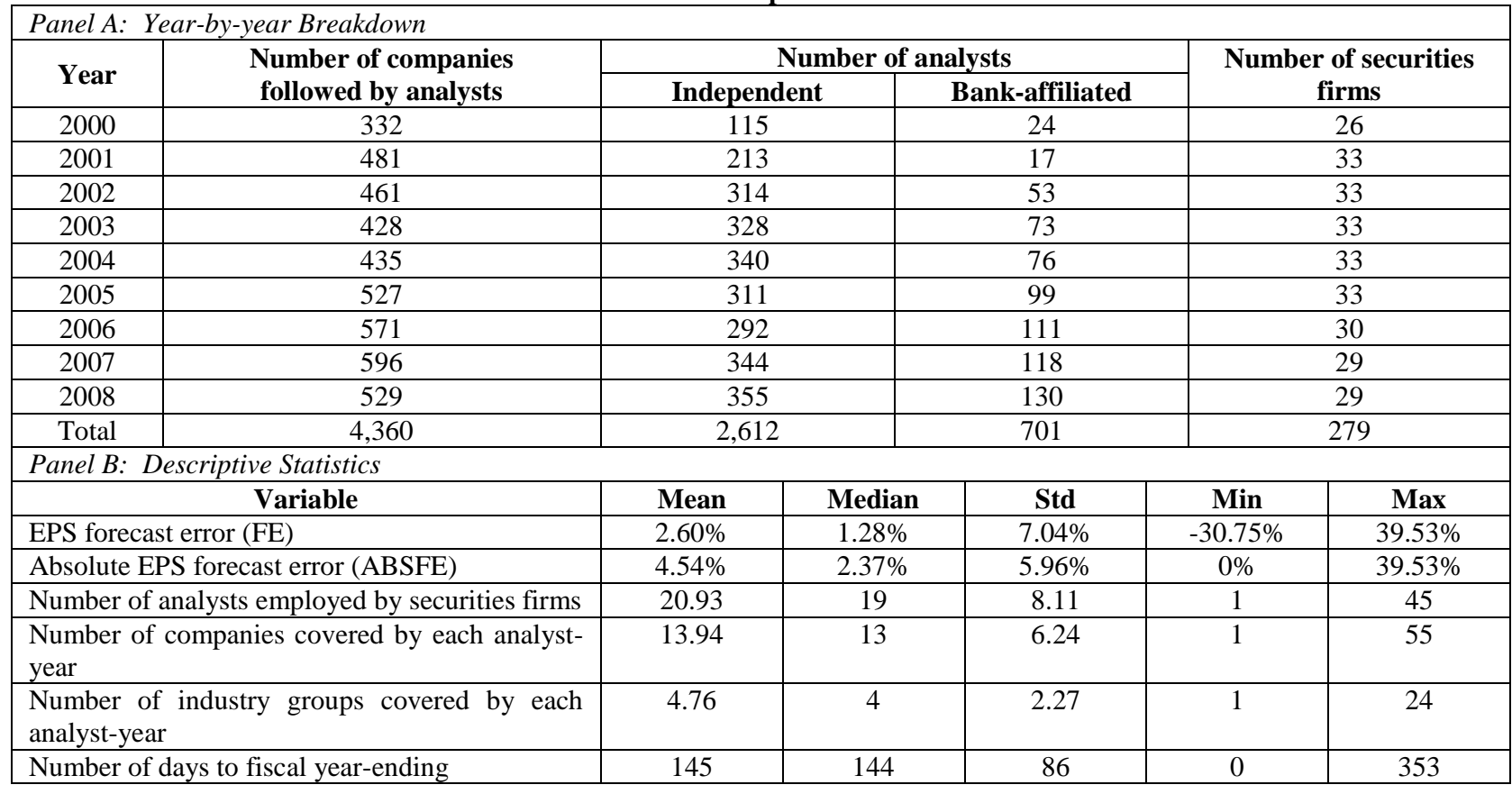


Panel A presents a year-by-year breakdown of analyst coverage for companies belonging to banks versus independent companies. The number of distinctive companies is 1,157 and the number of distinctive analysts is 972 . The number of analysts who work for securities firms within banks versus independent analysts is also provided. Panel B presents the descriptive statistics for 106,034 earnings per share (EPS) forecasts and 102,178 stock recommendations. EPS forecast error is calculated as the ratio of the difference between the forecasted and actual EPS to the stock price, while absolute EPS forecast error represents the absolute value of the forecast error. The mean, median, standard deviation (std), minimum ( $\min )$, and maximum (max) of the following variables are also presented: the number of analysts employed by securities firms, number of companies covered by each analyst-year, number of industry groups covered by each analyst-year, and number of days to fiscal year-ending.

Panel B of Table 2 presents descriptive statistics of variables representing analyst characteristics. We calculate forecasting error (FE) and absolute forecasting error (ABSFE) using the forecasted EPS and actual EPS. Following Hong and Kubic (2003), we measure the forecast error by analyst $i$ for company $j$ on day $t$ as follows:

$\mathrm{FE}_{\mathrm{ijt}}=\frac{\mathrm{F}_{\mathrm{ijt}}-\mathrm{A}_{\mathrm{j}}}{\mathrm{P}_{\mathrm{jt}-1}}$

where $\mathrm{F}_{\mathrm{ijt}}$ is the forecast of a year-end EPS issued by analyst $i$ for company $j$ on day $t, \mathrm{~A}_{\mathrm{j}}$ is the actual year-end EPS of the company $j$ for the year, and $\mathrm{P}_{\mathrm{jt}-1}$ is a closing stock price of the company on day $t-1$. ABSFE is the absolute value of the EPS forecast error (FE).

Since outliers can distort our tests, we winsorize the top and bottom one percent of EPS forecast errors. The mean (median) FE is $2.60 \%$ (1.28\%) with a standard deviation of $7.04 \%$, which indicates that the analysts tend to make optimistic EPS forecasts on the companies covered. The mean (median) ABSFE is $4.54 \%$ (2.37\%) with a standard deviation of $5.96 \%$.

The mean (median) number of analysts employed by each securities firm each year is about 21 (19) analysts. The mean number of companies covered by each analyst-year is 13.94 while the mean number of industries covered by each analyst-year is 4.67 . The mean number of days from the day of issuing analysts' reports to the fiscal year-end date is 145 days.

\section{EMPIRICAL FINDINGS}

Using univariate tests, we first test whether there is a difference in analyst characteristics between independent and bank-affiliated analysts and report the results in Table 3. The mean (median) EPS forecast error of $2.71 \%(1.34 \%)$ made by independent analysts is significantly higher than that of $2.09 \%(1.02 \%)$ made by bankaffiliated analysts with a p-value of less than 0.01 . This suggests that independent analysts tend to issue more optimistic EPS forecasts for industrial companies covered than bank-affiliated analysts. The difference in absolute EPS forecast errors between independent vs. bank-affiliated analysts indicates that bank-affiliated analysts produce more accurate EPS forecasts than independent analysts.

Table 3: Comparison Of Forecast Characteristics By Independent VS. Bank-Affiliated Analysts

\begin{tabular}{|l|c|c|c|c|c|c|}
\hline \multirow{2}{*}{ Variable } & \multicolumn{2}{|c|}{ Independent analysts } & \multicolumn{2}{c|}{$\begin{array}{c}\text { Bank-affiliated } \\
\text { analysts }\end{array}$} & \multicolumn{2}{c|}{$\begin{array}{c}\text { Difference tests } \\
\text { (p-values) }\end{array}$} \\
\cline { 2 - 7 } & Mean & Median & Mean & Median & Mean & Median \\
\hline EPS forecast error (FE) & $2.71 \%$ & $1.34 \%$ & $2.09 \%$ & $1.02 \%$ & $<0.01$ & $<0.01$ \\
\hline Absolute EPS forecast error (ABSFE) & $4.60 \%$ & $2.39 \%$ & $4.27 \%$ & $2.24 \%$ & $<0.01$ & $<0.01$ \\
\hline $\begin{array}{l}\text { Number of analysts employed by securities } \\
\text { firms }\end{array}$ & 20.49 & 19.00 & 23.04 & 23.00 & $<0.01$ & $<0.01$ \\
\hline $\begin{array}{l}\text { Number of companies covered by each } \\
\text { analyst-year }\end{array}$ & 14.30 & 13.00 & 12.21 & 12.00 & $<0.01$ & $<0.01$ \\
\hline $\begin{array}{l}\text { Number of industry groups covered by } \\
\text { each analyst-year }\end{array}$ & 4.90 & 5.00 & 4.10 & 4.00 & $<0.01$ & $<0.01$ \\
\hline \begin{tabular}{l} 
Number of days to fiscal year-ending \\
\hline
\end{tabular} & 143 & 142 & 154 & 155 & $<0.01$ & $<0.01$ \\
\hline
\end{tabular}


Univariate tests of the effects of bank affiliation on the sample are presented. The table presents the forecasts made by independent analysts versus bank-affiliated analysts. EPS forecast error is calculated as the ratio of the difference between the forecasted and actual EPS to the stock price while absolute forecast error represents the absolute value of the forecast error. In addition, the number of analysts employed by securities firms, number of companies covered by each analyst-year, number of industry groups covered by each analyst-year, and number of days to fiscal year-ending are compared.

Following previous literature, we use number of analysts employed by securities firms each year to measure securities firm size. Table 3 shows that bank-affiliated securities firm is significantly larger than independent securities firms. Clement (1999) argues that analysts who work for larger securities firms can use better resources, which result in a higher research quality. We use the number of companies and industry groups covered by each analyst-year to measure workloads of the analysts. The table presents that bank-affiliated analysts cover significantly fewer number of companies and industries than independent analysts. These results suggest that bank-affiliated analysts make more accurate EPS forecasts than independent analysts since they have more resources to use in their securities firms and a lighter workload. The table also shows that the number of days from the issuance date of an analysts' research report to fiscal year-ending date is more for bank-affiliated analysts than independent analysts.

The ordinary least squares (OLS) regression results presented in Table 4 confirm the univariate test results in Table 3. Regression models include variables to control for company and analysts' characteristics following previous literature. In Model 1, the dependent variable is EPS forecast errors (FE). To control for the level of information asymmetry associated with the covered company, we include a natural log of assets, a ratio of long-term debt to assets, a ratio of intangible assets to assets, and a natural $\log$ of the number of analysts following in the regressions. The coefficient on the log of assets is significantly negative $(-0.004 ; \mathrm{p}<0.01)$, indicating that analysts' EPS forecasts tend to be more accurate for larger companies. The coefficients on the ratio of long-term debt to assets and the ratio of intangible assets to assets are all positive and statistically significant, indicating that analysts' forecast errors are bigger for the companies with higher leverage and more intangible assets. The coefficient on the number of analysts following is significantly negative, indicating that analysts' EPS forecasts tend to be more accurate for companies with less information asymmetry.

Table 4: Determinants Of EPS Forecast Error (FE)-OLS Regression Analysis

\begin{tabular}{|c|c|c|}
\hline Variable & $\begin{array}{c}\text { Forecast errors (FE) } \\
\text { Model } 1\end{array}$ & $\begin{array}{l}\text { Averaged forecast errors by analysts, } \\
\text { companies, and year Model } 2\end{array}$ \\
\hline \multirow[t]{2}{*}{ Intercept } & 0.144 & 0.114 \\
\hline & $(<0.01)$ & $(<0.01)$ \\
\hline \multicolumn{3}{|l|}{ Company characteristics } \\
\hline \multirow[t]{2}{*}{ Log (Assets) } & -0.004 & -0.005 \\
\hline & $(<0.01)$ & $(<0.01)$ \\
\hline \multirow[t]{2}{*}{ Ratio of long-term debt-to-assets } & 0.053 & 0.054 \\
\hline & $(<0.01)$ & $(<0.01)$ \\
\hline \multirow[t]{2}{*}{ Ratio of intangible assets-to-assets } & 0.061 & 0.061 \\
\hline & $(<0.01)$ & $(<0.01)$ \\
\hline \multirow[t]{2}{*}{ Log (number of analysts following) } & -0.015 & -0.012 \\
\hline & $(<0.01)$ & $(<0.01)$ \\
\hline \multicolumn{3}{|l|}{ Analyst characteristics } \\
\hline \multirow[t]{2}{*}{$\log$ (number of analysts per securities firm) } & -0.002 & 0.001 \\
\hline & $(<0.01)$ & $(0.49)$ \\
\hline \multirow{2}{*}{$\begin{array}{l}\text { Log (number of companies covered by each } \\
\text { analyst-year) }\end{array}$} & 0.004 & 0.008 \\
\hline & $(<0.01)$ & $(<0.01)$ \\
\hline \multirow[t]{2}{*}{$\log$ (number of days to fiscal year-ending) } & 0.006 & 0.006 \\
\hline & $(<0.01)$ & $(<0.01)$ \\
\hline \multirow[t]{2}{*}{ Dummy for bank analysts } & -0.001 & -0.003 \\
\hline & $(0.01)$ & $(<0.01)$ \\
\hline Year dummies & Included & \\
\hline $\mathrm{N}$ & 96,194 & 23,624 \\
\hline Adjusted R-squared (\%) & 7.71 & 5.93 \\
\hline
\end{tabular}


EPS forecast error is calculated as the ratio of the difference between the forecasted and actual EPS to the stock price. Log (Assets) is the natural log of the total assets. Dummy for bank analysts is a dummy variable that takes the value 1 if the forecast is issued by bank-affiliated analysts. The p-values for the coefficients are provided in parentheses.

The regression models also control for the size of the securities firm issuing the forecast (a natural log of analysts per securities firm), the number of companies covered by the analyst issuing the forecast, and the number of days until the end of the fiscal year. The coefficients of these control variables are all in the expected direction. Larger securities firms would be expected to be more experienced and employ a higher number of more talented analysts, leading to lower forecast errors. As expected, the result in Table 4 shows a negative association between the number of analysts working for a securities firm and the accuracy in EPS forecast. A higher number of companies covered by an analyst should reduce the available time and effort allocated to each forecast, leading to less accurate forecasts. Consistent with the expectation, the coefficient on a natural log of number of companies covered by each analyst-year is significantly positive. On the other hand, also as expected, the forecast errors are larger the longer the time between the recommendation and the release of the actual EPS at the end of the fiscal year.

Our main focus in Table 4 is to examine whether EPS forecast errors made by bank-affiliated analysts are different from those made by other analysts. To test this, we include a dummy variable indicating forecast errors made by the bank-affiliated analysts. The coefficient on the dummy variable is -0.001 with p-value of 0.01 in Model 1, which means that the bank -affiliated analysts make more accurate EPS forecasts.

We analyze analysts' average forecast errors by analyst, company, and year in Model 2 of Table 4, since most of the control variables are measured annually. The results in

Models 2 are similar to those in Model 1. The coefficient of the dummy variable for the bank-affiliated analysts in Model 2 is -0.003 with p-values of less than 0.01 . The results in Table 4 corroborate the findings presented in Table 3 that the bank-affiliated analysts tend to make more accurate earnings forecasts than independent analysts. This evidence is consistent with superior information hypothesis.

\section{CONCLUSION}

We investigate the effects of information sharing between commercial banks and securities firms under the same financial groups on the accuracy of bank-affiliated analysts' forecasts using Korean data over the period of 2000-2008. The bank-affiliated analysts under universal banking system can use the information generated by the commercial banks about the companies covered when they issue earnings forecasts.

The information sharing between commercial banks and securities firms under universal banking make the bank-affiliated analysts more accurate EPS forecasts. To be consistent with the superior information hypothesis, we find that bank-affiliated analysts make more conservative and accurate earnings forecasts than independent analysts. The evidence adds to the benefits of universal banking system. Commercial banks tend to accumulate the information on companies by making loans and monitoring. This study shows that the analysts can make more accurate earnings forecasts if they share the information generated by the commercial banks.

As for contribution to the strategy literature, the findings of this study confirm the notion that related diversification can benefit from the exchange and sharing of valuable information among business units, thus creating operational synergy.

\section{AUTHOR INFORMATION}

Chul Woo Moon is currently an associate professor of strategy at Sungkyunkwan University, Seoul, Korea. A Ph.D from the University of Maryland, College Park, Professor Moon held previous positions at Cleveland State University and Ewha Womans University. His current research interests include corporate diversification strategy 
and information sharing, theories on content-based competitive advantage, and arts-based creative management models. E-mail address: cwmoon@skku.edu

\section{REFERENCES}

1. Agrawal, A., Mark A. Chen, M. A., 2008. Do analyst conflicts matter? Evidence from stock recommendations. Journal of Law and Economics 51, 503-537.

2. Alavi, M., and Leidner, D.E. 2001. Knowledge management and knowledge management systems: Conceptual foundations and research issues. MIS Quarterly, 25, 1 (2001), 107-136.

3. Amit, R., and Livnat, J. 1988. Diversification strategies, business cycles and economic performance. Strategic Management Journal, 9, 99-110.

4. Bae, K. H., Stulz, R. M., Tan, H., 2008. A cross-country study of the performance of local analysts and foreign analysts. Journal of Financial Economics 88, 581-606.

5. Barber, B., Lehavy, and Trueman, B., 2007. Comparing the stock recommendation performance of investment banks and independent research firms, Journal of Financial Economics 85, 490-517.

6. Brav A. and Lehavy, R., 2003. An empirical analysis of analysts' target prices: short-term informativeness and long-term dynamics. Journal of Finance 58, 1933-1967.

7. Chang, J.J., Khanna, T., and Palepu, K., 2000. Analyst activity around the world, University of Pennsylvania working paper.

8. Clarke, J., Khorana, A., Patel, A., Rau, P.R., 2007. The impact of All-Star analyst job changes on their coverage choices and subsequent investment banking deal flow. Journal of Financial Economics 84, 713737.

9. Cliff, M. T., 2007. Do affiliated analysts mean what they say? Financial Management 36, 5-29.

10. Conroy, R. M., Fukuda, Y., and Harris, R. S., 1997. Securities houses and earnings forecasts in Japan: What makes for an accurate prediction? Financial Analysts Journal 53, 29-40.

11. Cowen, A., Groysberg, B., Healy, P., 2006. Which type of analyst firms are more optimistic? Journal of Accounting and Economics 41, 119-46.

12. Dugar, A. and Nathan, S., 1995. The effects of investment banking relationships on financial analysts' earnings forecasts and investment recommendations. Contemporary Accounting Research 12, 131-160.

13. Greenspan, A., 2007. The age of turbulence: Adventures in a new world. Penguin Press: New York.

14. Hong, H., Kubik, J. D., 2003. Analyzing the analysts: Career concerns and biased earnings forecasts. Journal of Finance 58, 313-51.

15. Houston, J., James, C., Karceski, J., 2006. What a difference a month makes: stock analyst valuations following initial public offerings. Journal of Financial and Quantitative Analysis 41, 111-137.

16. Irvine P.J.A., 2004, Do analysts generate trade for their firms? Evidence from the Toronto stock exchange. Journal of Accounting and Economics 30, 209-226.

17. Jacob, J., Rock, S., Weber, D. P., 2008. Do Non-investment bank analysts make better earnings forecasts? Journal of Accounting, Auditing, and Finance 23, 23-61.

18. Ljungqvist, A., Marston, F., Starks, L. T., Wei, K. D., Yan, H., 2007. Conflicts of interest in sell-side research and the moderating role of institutional investors. Journal of Financial Economics 85, 420-56.

19. Mehran, H., Stutz, R., 2007. The economics of conflicts of interest in financial institutions. Journal of Financial Economics 85, 267-96.

20. Michaely, R., Womack, K., 1999. Conflict of interest and the credibility of underwriter analyst recommendations. Review of Financial Studies 12, 653-86.

21. O'Brien, P.C., McNichols, M., Lin, H.-W., 2005. Analyst impartiality and investment banking relationships. Journal of Accounting and Research 43, 623-650.

22. Palich, L.E.; Cardinal, L.B.; and Miller, C.C. 2000. Curvilinearity in the diversification-performance linkage: An examination of over three decades of research. Strategic Management Journal, 21, 155-174.

23. Petersen, M.A., 2009, Estimating standard errors in finance panel data sets: comparing approaches, Review of Financial Studies 22, 435-480.

24. Rumelt, R.P. 1982. Diversification strategy and profitability. Strategic Management Journal, 3, 359-369.

25. Tallman, S., and Li, J.T. 1996. The effects of international diversity and product diversity on the performance of multinational firms. Academy of Management Journal, 39, 179-196. 
26. Tanriverdi, H. 2005. Information technology relatedness, knowledge management capability, and performance of multibusiness firms. MIS Quarterly, 29, 2, 311-334.

27. Teece, D.J. 1980. Economies of scope and the scope of the enterprise. Journal of Economic Behavior and Organization Science, 1 (3): 223-247.

28. Teece, D.J. 1982. Towards an economic theory of the multiproduct firm. Journal of Economic Behavior and Organization Science, 3 (1): 39-63.

\section{NOTES}

